\title{
How's Life at Home? New Evidence on Marriage and the Set Point for Happiness
}

\author{
Shawn Grover ${ }^{1} \cdot$ John F. Helliwell ${ }^{2}$
}

Published online: 19 December 2017

(c) The Author(s) 2017. This article is an open access publication

\begin{abstract}
Subjective well-being research has often found that marriage is positively correlated with well-being. Some have argued that this correlation may be result of happier people being more likely to marry. Others have presented evidence suggesting that the well-being benefits of marriage are short-lasting. Using data from the British Household Panel Survey, we control individual pre-marital well-being levels and find that the married are still more satisfied, suggesting a causal effect at all stages of the marriage, from prenuptual bliss to marriages of long-duration. Using new data from the United Kingdom's Annual Population Survey, we find that the married have a less deep U-shape in life satisfaction across age groups than do the unmarried, indicating that marriage may help ease the causes of the mid-life dip in life satisfaction and that the benefits of marriage are unlikely to be short-lived. We explore friendship as a mechanism which could help explain a causal relationship between marriage and life satisfaction, and find that well-being effects of marriage are about twice as large for those whose spouse is also their best friend.
\end{abstract}

Keywords Marriage · Happiness set point - U-shape - Life satisfaction · Marriage and friendship

John F. Helliwell

john.helliwell@ubc.ca

Shawn Grover

shawngrover@gmail.com

1 Vancouver School of Economics, 6000 Iona Drive, Vancouver, BC V6T 1L4, Canada

2 Canadian Institute for Advanced Research, Vancouver School of Economics, 6000 Iona Drive,

Vancouver, BC V6T 1L4, Canada 


\section{Introduction}

Although cross-sectional studies, ${ }^{1}$ especially in western industrial societies, ${ }^{2}$ have shown those who are married (and those living as married) to have significantly higher life satisfaction than those who are single, separated, divorced or widowed, some widely cited studies using panel data from Germany and the United Kingdom have suggested that while life satisfaction may rise for a few years after marriage it eventually falls back to premarriage levels.

This apparent inconsistency between the cross-sectional and life course studies poses two sorts of threat to the growing interest in using subjective well-being as a measure of human progress. First, if major changes in life circumstances have only temporary effects of life evaluations, then this casts doubt on the value of life satisfaction as a welfare measure. Second, if the cross-sectional and panel methodologies give very different estimates of the value of marriage, then confidence drops in both methodologies, and suspicion arises that the cross-sectional estimates are capturing either selection effects or some other person-specific characteristics not accounted for elsewhere. In particular, those who marry tend to be more social, healthier, better educated and have more engaging jobs, all features of life likely to increase happiness with or without marriage. And there is lots of evidence that happier people tend to attract more friends and potential partners (Stutzer and Frey 2006). All of these factors could explain cross-sectional estimates that were higher than those obtained by following specific individuals through their lives.

The existence of high levels of adaptation, or reversion to fixed life satisfaction set points determined by genetics or other stable personality traits (Brickman and Campbell 1971), by contrast, would lead to smaller cross-sectional as well as panel estimates, since for each individual there would be only a few happy post-marriage years before return to the set point. ${ }^{3}$

The aim of this paper is to use measures of life satisfaction from different surveys to estimate the size and permanence of the effects of marriage on subjective well-being. Using methods that we argue provide secure estimates of the effects of marriage in the British Household Panel Survey (BHPS), we find estimates of positive effects of marriage, even when controlling for pre-marital life satisfaction. These estimates are not only significant in size but also close in magnitude to those obtained from cross-sectional estimates, thus increasing the credibility of both estimation methods.

We then dig deeper into the possible sources of these effects. We first look at the age patterns for the positive effects of marriage, finding that the U-shape in age is less marked for those who are married. In the same vein, we explore the role of friendship within marriage, finding that in our United Kingdom data the well-being benefits of marriage are much greater for those who also regard their spouse as their best friend.

\footnotetext{
1 See Gove et al. (1983), Di Tella et al. (2003), Peiró (2006) and Stack and Eshleman (1998).

2 Based on the implied acronym, such western industrialized rich democracies have been labeled WEIRD. See Henrich et al. (2010), who argue that experiments in WEIRD contexts may be misleading guides to the lives lived by most of the world's population. The special nature of WEIRD countries extends to crosssectional estimates of the effects of marriage on life evaluations. If the world population is divided among 7 global regions, significant positive effects of marriage, relative to being single, are found in only the regions containing the WEIRD countries and in the middle east. See Helliwell et al. (2010), Table 10.2.

3 See Lucas (2007, 76) and Suh et al. (1996).
} 


\subsection{Setting the Stage}

Two widely cited papers have used panel data to show life satisfaction gains after marriage that are dissipated within a few years. First, Lucas et al. (2003) analyzed the German Socio-Economic Panel Study (GSOEP) and concluded that the set point theory applies to marriage because they found that married individuals have a higher pre-marital happiness baseline than those who will remain unmarried and although they report increased life satisfaction around the time of their marriage their subsequent well-being reverts to their pre-marital baseline after a few years. Second, Clark and Georgellis (2013) used the BHPS to show that married people are more satisfied in the years immediately before and after their marriage, but that marriage had a negligible effect for individuals who had been married for at least 5 years.

Subsequent research, some by the same authors, has questioned the reliability of these findings. Zimmermann and Easterlin (2006) analyzed the GSOEP and found that when allowing age to vary "individuals who remain married two or more years do not revert to their baseline value before marriage". "The authors explain that their results differ from Lucas et al. (2003) because of "their [Lucas et al.] failure to treat age as varying with time, and thus to control for life circumstances that affect life satisfaction negatively". 5

Yap et al. (2012) used a propensity score matching ${ }^{6}$ method to match unmarried individuals who would go on to be married to similar individuals who would remain unmarried for the duration of the sample and found that while the well-being of the married sample rose around the time of their marriage and then fell, the well-being of the unmarried sample fell during the entire period. This finding is consistent with the U-shape in age as most people marry in their 20s and 30s when well-being is generally in decline. Thus this finding can explain why married individuals simultaneously revert to their premarital baseline and maintain a well-being advantage over their peers who remain unmarried. The same authors found similar results to hold in Switzerland ${ }^{7}$ and Australia. ${ }^{8}$

Qari (2014) used the GSOEP to show that the adaptation result is sensitive to the baseline period used. Qari found that "using 5 years prior to marriage as the relevant baseline year allows us to calculate utility while single more accurately. If we-instead of this-use only 1-2 years prior to marriage as the reference category, the same sample generates evidence of complete "adaptation" as in previous longitudinal studies". ${ }^{9}$ Thus, when analyzing the panel data results in the BHPS, we must be careful about which baseline we choose, noting that using individual fixed effects will implicitly invoke a baseline equivalent to the within-sample pre-marital years for those who eventually become married. If this time period is too short, as we find to be the case in the BHPS life satisfaction data, then the baseline is likely to be contaminated by the happy period during which friendship with the eventual marriage partner is being developed and enjoyed.

The use of fixed effects in panel data with rarely varying regressors is problematic. Beck (2001) noted this issue and said "although we can estimate [a model] with slowly changing

\footnotetext{
${ }^{4}$ Zimmermann and Easterlin (2006, 519).

5 Zimmermann and Easterlin (2006, 519).

6 The authors estimated a propensity score for each person using logistic regression to predict whether the person became married or not from sex, age, age squared, logarithmic household income, and education. Then they matched each married person to an unmarried person with closest propensity score.

7 Anusic et al. (2014a).

8 Anusic et al. (2014b).

9 Qari $(2014,36)$.
} 
independent variables, the fixed effect will soak up most of the explanatory power of these slowly changing variables. Thus, if a variable ... changes over time, but slowly, the fixed effects will make it hard for such variables to appear either substantively or statistically significant". ${ }^{10}$

Plumper and Troeger (2007) noted that variables can be time-invariant either by definition or because of the period or sample under analysis. The BHPS suffers from the latter problem as we only have 12 years of life satisfaction data. Marital status typically does not change much over short periods of time. In the BHPS, $92.73 \%$ of people who were single in a period remained single in the next period, $82.45 \%$ of people who were living as couple remained living as a couple in the next period and $97.83 \%$ of people who were married remained married in the next period. Plumper and Troeger (2007) proposed a method entitled fixed effects vector decomposition (FEVD) to deal with time-invariant (or rarely so) regressors and Boyce (2010) applied the method to life satisfaction and marital status and found that the marriage benefit was nearly three times larger in a model using FEVD rather than a model just using fixed effects. This suggests that the limited variance of marital status in the panel data is a real problem with significantly large effects.

The anticipatory effects of marriage and the use of lags and leads make the relatively invariant nature of the BHPS even more questionable. Clark and Georgellis (2013) used dummies for four periods prior to marriage and five periods after marriage. Thus, the longterm effect of marriage, which is the effect after five periods, can be compared to the premarital baseline only if someone has been in the sample for that entire period. This would require someone to have at least five unmarried periods and at least six married periods. We shall show the importance of this restriction, and hence the limitations of fixed effects estimation, by using a base point slightly farther in advance of the wedding date, making use of fixed effects estimation in the same way as Clark and Georgellis (2013).

\section{Data and Methods}

\subsection{Data and Summary Statistics}

This paper uses two data sets: the BHPS and the UK APS. The summary statistics for the variables we have used from each of these two surveys are shown in Appendix Tables 4 and 5. Each is used for a different purpose.

The BHPS is the key longitudinal survey we use to estimate the effects of marriage in a way that fully accounts for the reverse channels of causation running from happiness to marriage. The BHPS also contains a key friendship question permitting us to test the interaction between marriage and friendship.

The BHPS is a panel data set with 18 waves, collected from 1991 to 2009 in the United Kingdom. The BHPS's principal well-being measure is overall life satisfaction, where respondents are asked "How dissatisfied or satisfied are you with your life overall" and scores are measured on a 1-7 scale. The BHPS has overall life satisfaction only for Waves 6-10 and 12-18, thus these waves will be the principal focus of this paper's analysis.

\footnotetext{
${ }^{10}$ Beck (2001, 285). Switek and Easterlin (2016) implicitly include fixed effects by estimating the effects of several life transitions on life satisfaction in a panel of young Swedish adults. They estimate significant life satisfaction gains from transitions into partnerships (including marriage and cohabitation) and losses upon exiting, but do not test explicitly for subsequent reversion to possible baselines.
} 
Overall, the BHPS surveyed approximately 30,000 individuals; however, not all respondents completed all waves.

The much larger UK APS provides the sample size and power to show the differences between the life satisfaction among the married, the unmarried, and the never-married for all age groups. This permits a strong indirect test of the adaptation hypothesis, which would require that the positive effects of marriage be heavily clustered in the age range in which marriages typically take place. The survey also permits us to show that the crosssectional U-shape in happiness is much flatter for the married than for others,

The UK APS is a cross-sectional dataset with 328,665 observations collected between May 2011 and April 2013 in the United Kingdom. The UK APS data set has four relevant well-being measures: life satisfaction, worthwhileness, anxiety and happiness. We use the life satisfaction measure, where respondents are asked, on a scale from 0 to 10 "Overall, how satisfied are you with your life nowadays?" We concentrate on the life satisfaction measure for two reasons: it has been the primary variable in other research, and it provides, since it is an evaluation of life as a whole, the best overarching measure of the quality of life. $^{11}$

\subsection{Methods and Tests}

There are several stages to our analysis. First we replicate the Clark and Georgellis (2013) analysis, using the BHPS data, with their lag structures, and the same fixed effects estimation technique to show, as they do, that for those who have been married at least 6 years, life satisfaction is not significantly higher than at their chosen pre-marriage base point. Then we shall show the importance of using a longer and more plausible premarriage period by limiting the sample to those with at least five single periods to ensure that the baseline period is not driven by the periods leading up to marriage.

Next, we shall use the BHPS data to show that the risk of reverse causation is real, and must be accounted for properly. To provide a likely upper-bound estimate of the possible causal effects running from happiness to marriage, we shall estimate the impact of life satisfaction ten periods ago on probability of marriage considering only the population that was unmarried ten, nine and eight periods ago. The results will show significant reverse causality.

The inclusion of previous life satisfaction is a direct way of purging our estimated marriage effects of the reverse effects running from happiness to marriage, as well as from other stable factors that might raise both marriage prospects and happiness. This we will do by comparing two models, the first of which makes no attempt to allow for reverse causation, while the other also includes lagged life satisfaction from ten periods ago. ${ }^{12}$ Both equations include age, age squared, health limitations and log income as control variables, and in both cases, observations are only included from waves where lagged life satisfaction from ten periods ago is available (i.e., only waves 16 to 18) and where the individual was unmarried ten, nine, eight, seven and six periods ago, thereby including only individuals with five or more unmarried years prior to their marriage. OLS estimation

\footnotetext{
11 For a comparison of life evaluations and emotional reports, see Helliwell and Wang (2012, 13-16).

12 Note that the U-shape in age, as defined by the negative and positive coefficients on age and age squared respectively, disappears when we add previous life satisfaction. This parallels Frijters and Beatton (2012), who find that inclusion of individual fixed effects also removes the U-shape in age. In our case the reason is likely to be that the previous life satisfaction variable embodies a substantial part of the age effect, while in their case it may be because entries to and exits from the survey population may cause individual fixed effects to also include an age component.
} 
will be used, with standard errors calculated assuming that residuals are clustered at the level of the individual respondent. We shall decompose our average results to show the effects for different stages of marriage.

Following this direct estimation using longitudinal data, we use much larger samples of data from the United Kingdom Annual Population Survey (UK APS) to show the life satisfaction differences between the ever married and the never married, in order to see if those patterns are consistent with the set point hypothesis.

Finally, we shall turn to consider some of the likely channels through which marriage might be affecting life satisfaction. We shall first do this by using the much larger APS data samples to show that marriage appears to help individuals to deal with midlife pressures. We then return to the BHPS data to test for a possible interaction effect between marriage and friendship.

\section{Results and Discussion}

\subsection{The Fragility of Fixed Effects Estimation}

We first used fixed effects estimation using the same lags and leads as imposed by Clark and Georgellis (2013), to estimate the long-term marriage effect for people who have been married at least 6 years. It is approximately zero. However, when we shifted the baseline so as to include individuals in the regression only if they have at least five periods of a "never married" status, then the long-term effect returns to being large and significant at the 5\% level (results in Appendix Table 6). We believe that this is a more appropriate specification. Failing to ensure that people have at least 5 years to use as a pre-marital baseline causes the anticipatory well-being effects of marriage and the limitations of the BHPS to falsely drive down the estimated impact of marriage.

\subsection{The Likelihood of Reverse Causation}

We assessed the likelihood of such reverse causation by using life satisfaction of ten periods previous to explain the likelihood of becoming married 8, 9 or 10 years later. If we find a significant effect, then we have convincing evidence that selection effects are significant, and need to be accounted for in any credible attempt to estimate the causal effect of marriage on life satisfaction. We found that an increase of one point on the life satisfaction scale is associated with an increase in probability of marriage of $1.37 \%$. This effect is significant at the $1 \%$ level. For perspective, the mean probability of someone unmarried in each of ten, nine and eight periods ago being married in the current period is $22.74 \%$. This indicates that the selection effects found in papers such as Stutzer and Frey (2006) are present in the BHPS data as well.

\subsection{Using Previous Life Satisfaction to Eliminate the Selection Effect}

The existence of a selection effect does not preclude a true causal effect from marriage to life satisfaction. In Table 1 we present regressions explaining individual life satisfaction estimated with and without the inclusion of previous life satisfaction to test whether the reverse causation can fully explain the life satisfaction difference between the married and unmarried. It cannot. 
Table 1 Life satisfaction controlling for earlier life satisfaction—dependent variable is life satisfaction on a $1-7$ scale

\begin{tabular}{|c|c|c|c|c|c|}
\hline & $\begin{array}{l}\text { No Prev Lf } \\
\text { Sat }\end{array}$ & $\begin{array}{l}\text { With Prev Life } \\
\text { Sat }\end{array}$ & $\begin{array}{l}\text { With } \\
\text { children }\end{array}$ & $\begin{array}{l}\text { With } \\
\text { gender }\end{array}$ & $\begin{array}{l}\text { With children and } \\
\text { gender }\end{array}$ \\
\hline Married & $\begin{array}{l}0.586 * * * \\
(0.056)\end{array}$ & $\begin{array}{l}0.499 * * * \\
(0.049)\end{array}$ & $\begin{array}{l}0.550 * * * \\
(0.053)\end{array}$ & $\begin{array}{l}0.407 * * * \\
(0.065)\end{array}$ & $\begin{array}{l}0.502 * * * \\
(0.070)\end{array}$ \\
\hline livingascouple & $\begin{array}{l}0.369 * * * \\
(0.056)\end{array}$ & $\begin{array}{l}0.307 * * * \\
(0.049)\end{array}$ & $\begin{array}{l}0.338 * * * \\
(0.050)\end{array}$ & $\begin{array}{l}0.307 * * * \\
(0.050)\end{array}$ & $\begin{array}{l}0.347 * * * \\
(0.051)\end{array}$ \\
\hline Divorced & $\begin{array}{l}-0.104 \\
(0.088)\end{array}$ & $\begin{array}{l}-0.006 \\
(0.078)\end{array}$ & $\begin{array}{l}0.003 \\
(0.077)\end{array}$ & $\begin{array}{l}0.002 \\
(0.078)\end{array}$ & $\begin{array}{l}0.015 \\
(0.078)\end{array}$ \\
\hline Widowed & $\begin{array}{l}0.098 \\
(0.111)\end{array}$ & $\begin{array}{l}0.091 \\
(0.097)\end{array}$ & $\begin{array}{l}0.103 \\
(0.097)\end{array}$ & $\begin{array}{l}0.103 \\
(0.097)\end{array}$ & $\begin{array}{l}0.120 \\
(0.098)\end{array}$ \\
\hline Separated & $\begin{array}{l}-0.162 \\
(0.251)\end{array}$ & $\begin{array}{l}-0.162 \\
(0.217)\end{array}$ & $\begin{array}{l}-0.145 \\
(0.217)\end{array}$ & $\begin{array}{l}-0.156 \\
(0.216)\end{array}$ & $\begin{array}{l}-0.140 \\
(0.217)\end{array}$ \\
\hline Female & $\begin{array}{l}-0.058 \\
(0.046)\end{array}$ & $\begin{array}{l}-0.014 \\
(0.040)\end{array}$ & $\begin{array}{l}0.001 \\
(0.040)\end{array}$ & $\begin{array}{l}-0.047 \\
(0.046)\end{array}$ & $\begin{array}{l}-0.046 \\
(0.049)\end{array}$ \\
\hline $\begin{array}{l}\text { Age at date of } \\
\text { interview }\end{array}$ & $\begin{array}{l}-0.029^{* *} \\
(0.009)\end{array}$ & $\begin{array}{l}-0.004 \\
(0.008)\end{array}$ & $\begin{array}{l}-0.005 \\
(0.008)\end{array}$ & $\begin{array}{l}-0.004 \\
(0.008)\end{array}$ & $\begin{array}{l}-0.006 \\
(0.008)\end{array}$ \\
\hline Agesq & $\begin{array}{l}0.037 * * * \\
(0.009)\end{array}$ & $\begin{array}{l}0.010 \\
(0.008)\end{array}$ & $\begin{array}{l}0.011 \\
(0.008)\end{array}$ & $\begin{array}{l}0.010 \\
(0.008)\end{array}$ & $\begin{array}{l}0.011 \\
(0.008)\end{array}$ \\
\hline Health Limits & $\begin{array}{l}-0.926 * * * \\
(0.065)\end{array}$ & $\begin{array}{l}-0.774 * * * \\
(0.059)\end{array}$ & $\begin{array}{l}-0.772 * * * \\
(0.059)\end{array}$ & $\begin{array}{l}-0.775 * * * \\
(0.059)\end{array}$ & $\begin{array}{l}-0.771 * * * \\
(0.059)\end{array}$ \\
\hline LogIncome & $\begin{array}{l}0.041 \\
(0.023)\end{array}$ & $\begin{array}{l}0.034 \\
(0.021)\end{array}$ & $\begin{array}{l}0.030 \\
(0.021)\end{array}$ & $\begin{array}{l}0.037 \\
(0.021)\end{array}$ & $\begin{array}{l}0.033 \\
(0.021)\end{array}$ \\
\hline LfSat10PeriodsAgo & & $\begin{array}{l}0.322 * * * \\
(0.015)\end{array}$ & $\begin{array}{l}0.321 * * * \\
(0.015)\end{array}$ & $\begin{array}{l}0.322 * * * \\
(0.015)\end{array}$ & $\begin{array}{l}0.322 * * * \\
(0.015)\end{array}$ \\
\hline OneChild & & & $\begin{array}{l}-0.181^{* *} \\
(0.057)\end{array}$ & & \\
\hline TwoChildren & & & $\begin{array}{l}-0.113 \\
(0.068)\end{array}$ & & \\
\hline ThreePlusChildren & & & $\begin{array}{l}-0.136 \\
(0.108)\end{array}$ & & \\
\hline MarriedAndFemale & & & & $\begin{array}{l}0.169^{*} \\
(0.082)\end{array}$ & $\begin{array}{l}0.111 \\
(0.087)\end{array}$ \\
\hline HasChild & & & & & $\begin{array}{l}-0.213 * * \\
(0.068)\end{array}$ \\
\hline HasChildAndFemale & & & & & $\begin{array}{l}0.102 \\
(0.091)\end{array}$ \\
\hline Constant & $\begin{array}{l}5.112 * * * \\
(0.303)\end{array}$ & $\begin{array}{l}2.970 * * * \\
(0.290)\end{array}$ & $\begin{array}{l}3.096 * * * \\
(0.292)\end{array}$ & $\begin{array}{l}2.964 * * * \\
(0.291)\end{array}$ & $\begin{array}{l}3.085 * * * \\
(0.292)\end{array}$ \\
\hline Observations & 5326 & 5326 & 5326 & 5326 & 5326 \\
\hline Adjusted R-squared & 0.125 & 0.233 & 0.235 & 0.234 & 0.236 \\
\hline
\end{tabular}

Standard errors in parentheses

* Significant at 5\%; ** Significant at $1 \%$; *** Significant at $0.1 \%$

The inclusion of lagged life satisfaction as an independent variable lowers the coefficient on being married slightly from 0.586 to 0.499 . The effect remains highly significant $(p<.001)$. This indicates that selection effects do not fully explain why the married exhibit higher happiness levels than the unmarried. 
The equations also show results for those living as a couple, for whom the life satisfaction effects are approximately three-quarters as great as for the married. ${ }^{13}$ The effect of marriage increases from 0.499 to 0.550 when the number of children is controlled for, and remains highly significant. When an interaction term is included to show the difference between men and women in the well-being effect of marriage, the life satisfaction impact of marriage is shown to be 0.169 higher for females than males. This effect is significant at the $5 \%$ level.

We can also use the BHPS data to show the life satisfaction effects at different stages of the marriage relationship. We do this in Table 2 and Figs. 1 and $2 .{ }^{14}$ We estimate separate effects for the 2-year period prior to marriage, the period including marriage and the three following years, years 4-6 following marriage, and all those with marriages entered seven or more years previously. Table 2 shows the estimation results both without and with the inclusion of life satisfaction 10 years previously. Figures 1 and 2 show the positive effects of the marriage relationship, with the comparison group including respondents who remain unmarried and those who become married more than 2 years later. The whisker lines showing the $95 \%$ confidence intervals of the estimates reveal highly significant life satisfaction effects in each stage of the marriage, with the peak being during the marriage and immediate post-marriage years. The effects are smaller when lagged life satisfaction is included, but they remain highly significant even for marriages more than 7 years old, at 0.2 points on the seven point scale. This is very close to the equivalent cross-sectional estimates we provide later from the much larger UK APS sample, where life satisfaction is measured on a 0 to 10 scale.

The estimates of the average well-being effects of marriage may include some unhappy years that precede separation and divorce. Thus, the long-term well-being difference between the never-married and those who stay married may be greater than the above would suggest.

\subsection{Marriage and the U-Shape in Age}

If the benefits of marriage are fleeting and individuals subsequently return to their set-point levels of well-being, we would expect that the difference between the married and unmarried would be greatest at ages when many people of that age are recently married and much smaller at ages when fewer people are getting married. Given that the median of age of marriage in the United Kingdom is approximately 30.8 for men and 28.9 for women, ${ }^{15}$ adaptation and set-point theory would suggest that the difference between married and unmarried should be the greatest in one's late 20s and 30s, when marriage is typically more recent. But the cross-sectional evidence from the UK APS, as shown in Fig. 3, rules out this possibility, thus casting further doubt on the set-point interpretation of the marriage effect.

We find that the U-shape in the relationship between life satisfaction and age (Blanchflower and Oswald 2008; Piper 2015; Graham and Pozuelo 2017) exists for both the married and unmarried but is deeper for the unmarried, and the difference between

\footnotetext{
${ }^{13}$ Dush and Amato (2005) find a similar ranking, but a greater difference between marriage and living together, for their US sample.

14 We are grateful to a referee for suggesting this useful extension. To introduce an immediate pre-marriage group, we split the previous living-as-couple observations into two groups: those about to be married within 2 years, and all the remaining observations.

15 See Haurant (2013).
} 
Table 2 Life satisfaction impact of various marriage stages-dependent variable is life satisfaction on a $1-7$ scale

\begin{tabular}{|c|c|c|}
\hline & No Life Sat Control & With LifeSatControl \\
\hline marryWithinNextTwoPeriods & $\begin{array}{l}0.503 * * * \\
(0.093)\end{array}$ & $\begin{array}{l}0.491 * * * \\
(0.095)\end{array}$ \\
\hline marriedLastThreePeriods & $\begin{array}{l}0.621 * * * \\
(0.058)\end{array}$ & $\begin{array}{l}0.548 * * * \\
(0.052)\end{array}$ \\
\hline marriedFourtoSixPeriodsAgo & $\begin{array}{l}0.510 * * * \\
(0.069)\end{array}$ & $\begin{array}{l}0.399 * * * \\
(0.063)\end{array}$ \\
\hline marriedSevenPlusPeriods & $\begin{array}{l}0.351 * * * \\
(0.067)\end{array}$ & $\begin{array}{l}0.218^{* * * *} \\
(0.059)\end{array}$ \\
\hline livingascoupleNotPreMarry & $\begin{array}{l}0.329 * * * \\
(0.056)\end{array}$ & $\begin{array}{l}0.268 * * * \\
(0.050)\end{array}$ \\
\hline divorced & $\begin{array}{l}-0.126 \\
(0.084)\end{array}$ & $\begin{array}{l}-0.029 \\
(0.074)\end{array}$ \\
\hline widowed & $\begin{array}{l}0.059 \\
(0.107)\end{array}$ & $\begin{array}{l}0.054 \\
(0.095)\end{array}$ \\
\hline separated & $\begin{array}{l}-0.038 \\
(0.178)\end{array}$ & $\begin{array}{l}-0.074 \\
(0.153)\end{array}$ \\
\hline female & $\begin{array}{l}-0.040 \\
(0.042)\end{array}$ & $\begin{array}{l}-0.005 \\
(0.036)\end{array}$ \\
\hline age at date of interview & $\begin{array}{l}-0.031 * * * \\
(0.008)\end{array}$ & $\begin{array}{l}-0.006 \\
(0.008)\end{array}$ \\
\hline agesq & $\begin{array}{l}0.038 * * * \\
(0.008)\end{array}$ & $\begin{array}{l}0.013 \\
(0.008)\end{array}$ \\
\hline HealthLimits & $\begin{array}{l}-0.921 * * * \\
(0.062)\end{array}$ & $\begin{array}{l}-0.769 * * * \\
(0.056)\end{array}$ \\
\hline LogIncome & $\begin{array}{l}0.034 \\
(0.021)\end{array}$ & $\begin{array}{l}0.027 \\
(0.019)\end{array}$ \\
\hline LfSat10PeriodsAgo & & $\begin{array}{l}0.327 * * * \\
(0.014)\end{array}$ \\
\hline Constant & $\begin{array}{l}5.228 * * * \\
(0.279)\end{array}$ & $\begin{array}{l}3.070 * * * \\
(0.267)\end{array}$ \\
\hline Observations & 6176 & 6176 \\
\hline Adjusted R-squared & 0.119 & 0.232 \\
\hline
\end{tabular}

Standard errors in parentheses

* Significant at $5 \%$;* Significant at $1 \%$; ** Significant at $0.1 \%$

married and unmarried is greatest when people are in their late 40s and 50s. We can test whether this result is driven by disproportionate selection out of marriage, where people who are less satisfied with their lives will be more likely to divorce. This is done in Fig. 3, where we see similar results persist when we compare people who have ever been married to people who have never been married, although, as would be expected, the difference between the ever-married and the never-married is smaller than the difference between the married and unmarried. When comparing the effects by gender, marriage seems to be more important for women than men in middle ages, with the largest gap for those ages 51 to 55 where there is no overlap between the $95 \%$ confidence intervals. 


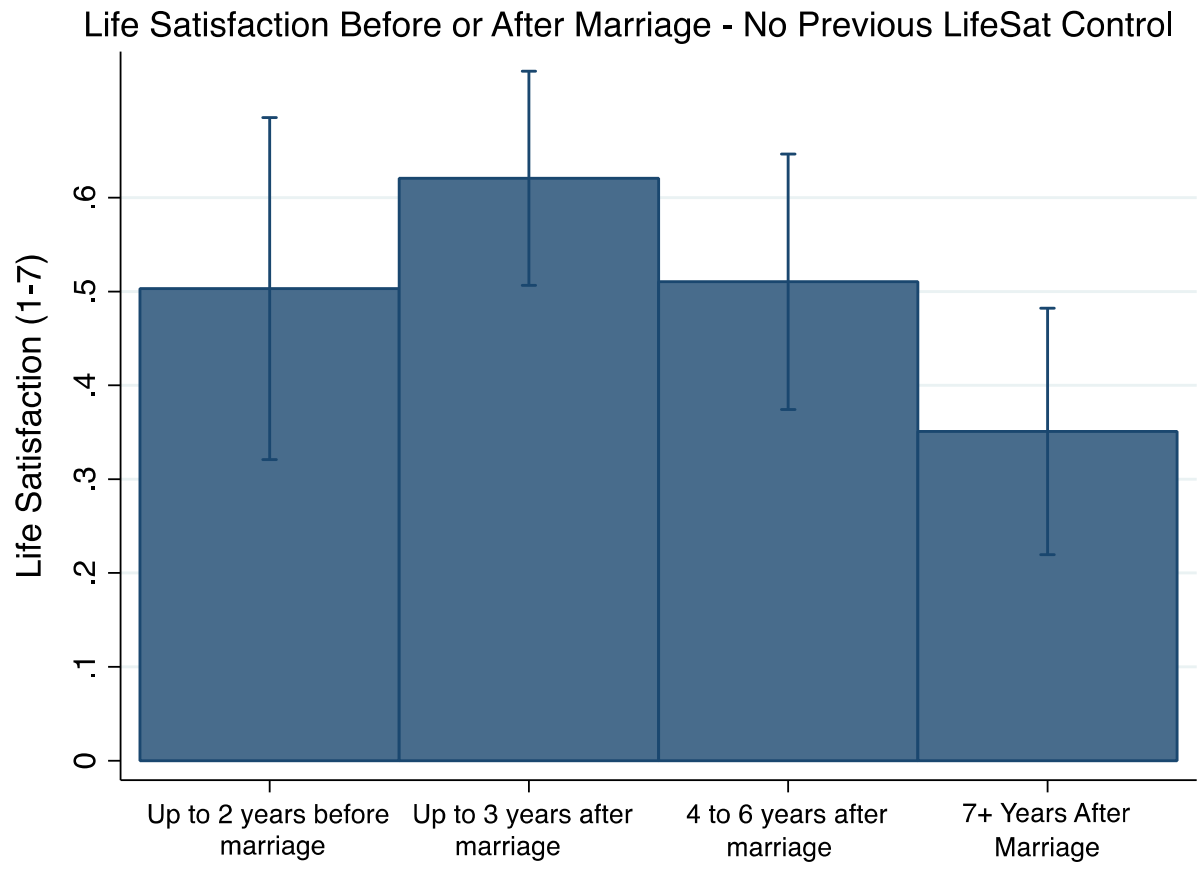

Fig. 1 BHPS life satisfaction impact before and after marriage-without controlling for previous life satisfaction

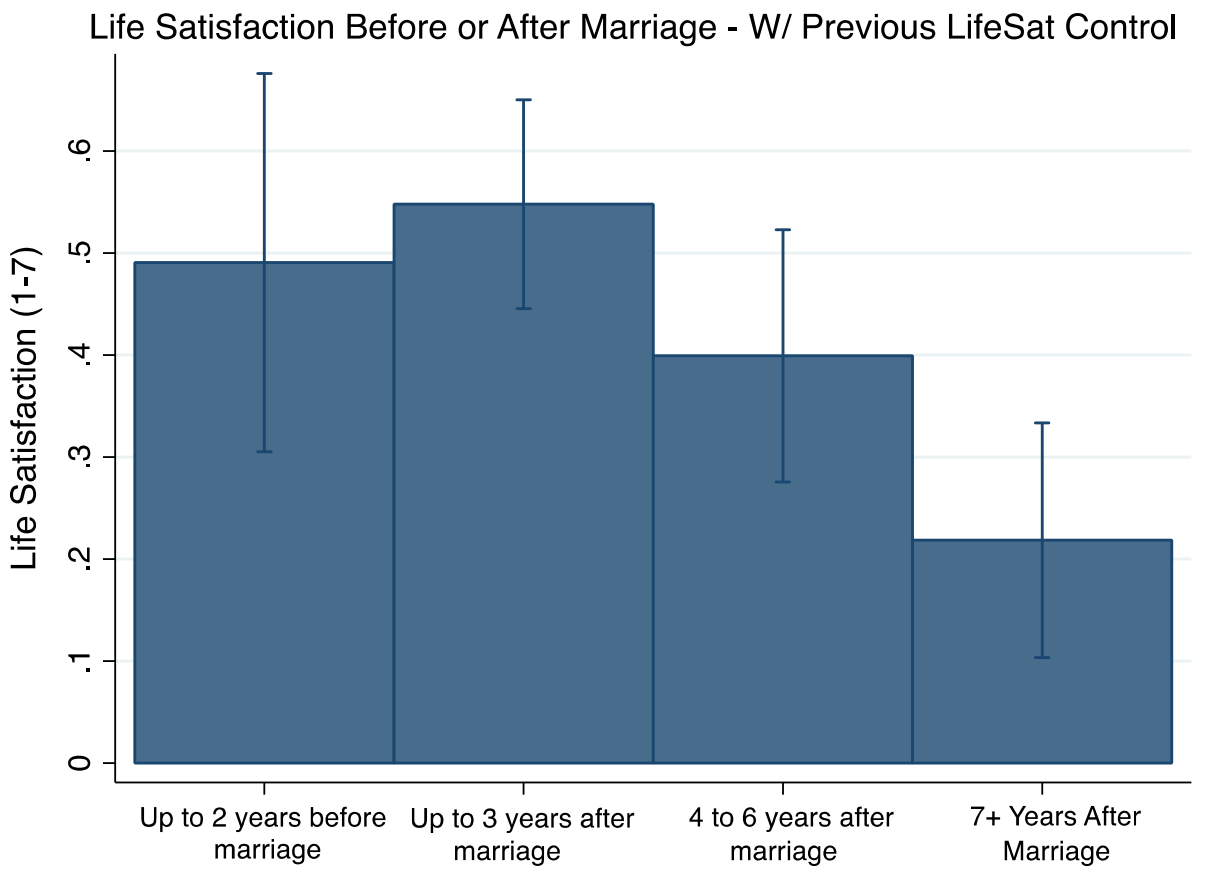

Fig. 2 BHPS life satisfaction impact before and after marriage-controlling for previous life satisfaction 


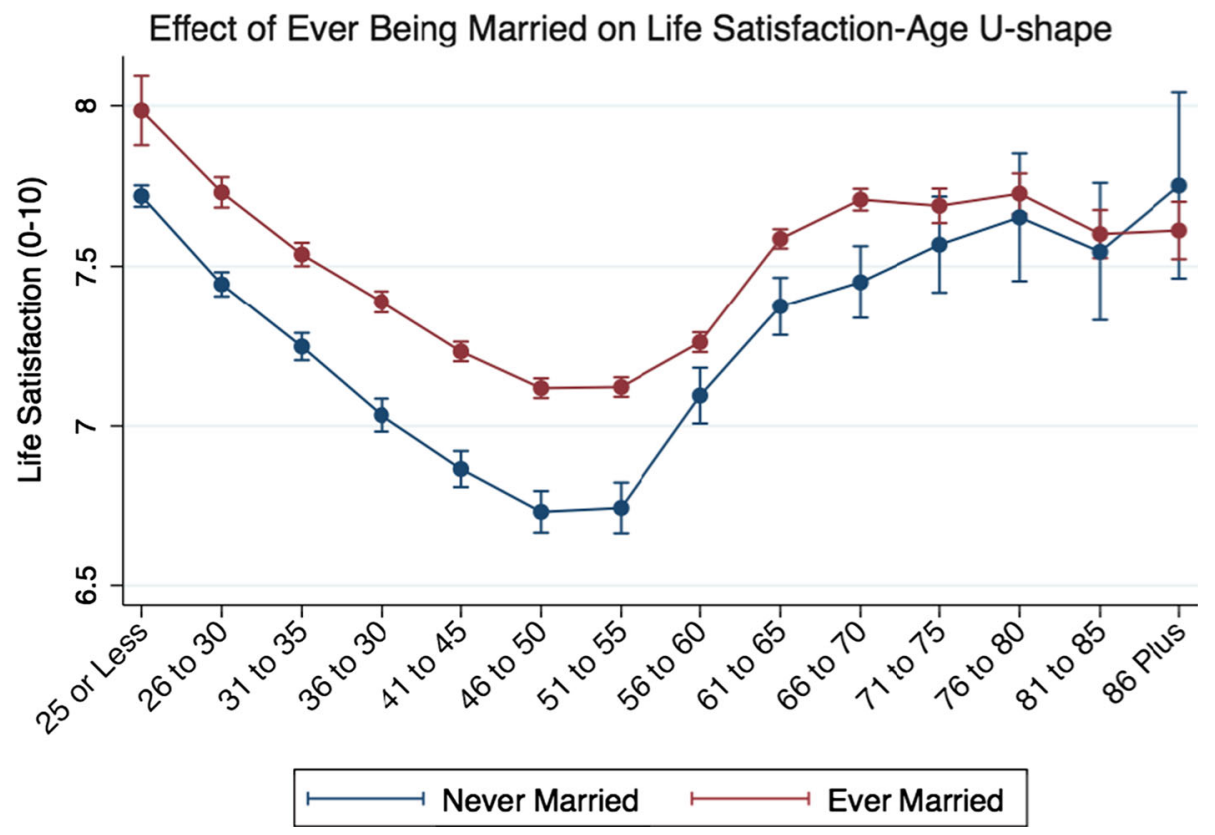

Fig. 3 Difference in U-shape between ever married and never married

One potential explanation for this result is that the social support provided by a spouse helps ease the stresses of middle age. It has already been shown, although with US data, that the U-shape in age, for daily measures of positive and negative affect, is smaller on weekends than of weekdays, and the determinants of the additional weekend happiness are shown to relate to the social contexts both at home and at work. ${ }^{16}$ The U-shape difference for the married is likely to have a similar explanation, although the BHPS does not have enough social context variables to permit more direct testing.

\subsection{Friendship as a Mechanism}

Although both friends and marriage are among the longest-standing and strongest independent correlates of life satisfaction (e.g. Myers 2000; Powdthavee 2008), there has been no study of the possibility of interactions between marriage and friendship as sources of life satisfaction. The likelihood of finding an interactive link between marriage and friendship was suggested to us by earlier Canadian results (Helliwell and Huang 2013) showing that the life satisfaction benefits of having more friends are significantly smaller for the married than the unmarried respondents. The BHPS provides an even more direct way of testing for a possible interaction between marriage and friendship, as it contains a question asking respondents to identify their best friend, permitting us to construct an interaction term for those respondents whose spouses are also their best friends.

Friendship could help explain why the benefits of marriage are not subject to adaptation, as one's partner provides unique social support for each challenge one faces in life. Additionally, friendship can help explain why people who are unmarried but living as a

${ }^{16}$ See Helliwell and Wang (2014, Table 6). 
couple enjoy most of the well-being benefits of marriage, especially if, as we find, their partner is also their best friend.

If friendship explains much of the well-being benefits of marriage, then life satisfaction should be higher for those whose spouses are also close friends. This is easily tested using the BHPS data, since respondents are asked about their closest friendship, with spouse or partner being one of the choices. Approximately half of married people and of those who are cohabiting list their partner as their best friend. ${ }^{17}$

To test the impact of having a best friend as a partner, we regressed life satisfaction on relationship status interacted with whether their partner is their best friend and standard controls and the results are presented in Table 3. Given their small number and unusual status, those who are neither married nor cohabitating but whose partner is still their best friend are omitted from the analysis. ${ }^{18}$ Those whose spouse or partner is also considered their best friend get almost twice as much additional life satisfaction from marriage or cohabitation as do others. ${ }^{19}$

Figure 4 shows that married individuals whose spouse is their best friend have higher life satisfaction than those who do not, even when controlling for age, gender, income, health limitations and previous life satisfaction. The same results hold for those who are cohabiting. When the effects are analyzed by gender, the well-being benefit of being married to one's best friend appears much higher for women than for men, although on average fewer women than men regard their spouse as their best friend. Further research is required to indicate how the friendship mechanism may differ for men and women or if there are other factors driving this result. ${ }^{20}$

Our finding that the happiness benefits of marriage flow largely through social channels, in particular though friendship, has strong parallels to the results of by Lim and Putnam (2010) for the life satisfaction effects of religion. They find that most or all of the subjective well-being benefits of religious involvement flow through the number of church friends, in particular those who share common values. The two pieces of research taken together suggest that friendship is a strong mediating factor for the life satisfaction consequences of two key life circumstances: marriage and religion. While all friends are important for happiness, those who share who share beliefs (in the Lim and Putnam example) or are married to each other (as in our results) are super-friends, with well-being effects apparently much larger than for friends on average.

\section{Summary and Conclusions}

This paper makes four contributions. First, even when controlling for pre-marital life satisfaction levels, those who marry are more satisfied than those who remain single. Second, contrary to past papers claiming full adaptation, the benefits of marriage persist in

\footnotetext{
17 There are differences by gender. Among the married, $64 \%$ of men and $48 \%$ of women respondents list their spouse as their best friend. For the cohabiting unmarried, the percentages are $57 \%$ for men and $48 \%$ for women.

18 Fewer than five percent of unmarried non-cohabiting respondents list their partners as their best friends.

19 The impact of being best friends with one's spouse was not significantly different for married individuals with and without children.

${ }^{20}$ Those reporting their spouses to be their best friends, are also more likely to report themselves to be happily married, a group found by Chapman and Guven (2016) to underlie the positive happiness effects of marriage. Dush and Amato (2005) find that the happiness of the marriage explains some but not all of the marriage effect.
} 
Table 3 Regression results by marital status and whether partner is best friend-dependent variable is life satisfaction on a $1-7$ scale

\begin{tabular}{lll}
\hline & W/o Lagged Life Sat & W/Lagged Life Sat \\
\hline married & $0.370^{* * *}$ & $0.225^{* * *}$ \\
& $(0.046)$ & $(0.043)$ \\
livingascouple & $0.366^{* * *}$ & $0.308^{* * *}$ \\
& $(0.077)$ & $(0.073)$ \\
MarriedXClosestFriendPartner & $0.232^{* * *}$ & $0.191^{* * *}$ \\
& $(0.038)$ & $(0.034)$ \\
LACXClosestFriendPartner & $0.227^{*}$ & 0.147 \\
age at date of interview & $(0.091)$ & $(0.087)$ \\
& $-0.034^{* * *}$ & -0.002 \\
agesq & $(0.007)$ & $(0.007)$ \\
& $0.041^{* * *}$ & 0.008 \\
HealthLimits & $(0.007)$ & $(0.006)$ \\
LogIncome & $-0.908^{* * *}$ & $-0.735^{* * *}$ \\
& $(0.053)$ & $(0.049)$ \\
female & -0.006 & -0.005 \\
& $(0.017)$ & $(0.016)$ \\
Life Satisfaction Ten Periods Ago & 0.025 & 0.019 \\
Constant & $(0.034)$ & $(0.031)$ \\
Observations & & $0.367 * * *$ \\
Adjusted R-squared & & $(0.014)$ \\
\hline
\end{tabular}

Standard errors in parentheses

* Significant at $5 \%$; ** Significant at $1 \%$; *** Significant at $0.1 \%$

the long-term, even if the well-being benefits are greatest immediately after marriage. Third, marriage seems to be most important in middle age when people of every marital status experience a dip in well-being. ${ }^{21}$ Fourth, those who are best friends with their partners have the largest well-being benefits from marriage and cohabitation, even when controlling for pre-marital well-being levels. The well-being benefits of marriage are on average about twice as large for those (about half of the sample) whose spouse is also their best friend.

Finally, we need to emphasize one important limitation. Our findings in relation to the set point are directly applicable only in those western countries for which there are suitable longitudinal surveys. Despite this qualification, our results showing that the long-term benefits of marriage are substantial help to solidify the important case that changes in key life circumstances have large and enduring consequences for life evaluations. These results combine with the large international differences in average life evaluations to demonstrate

${ }^{21}$ This result seems to be applicable globally, even in regions of the world where average effects of marriage are not positive, as shown in the longer working paper version of this paper. 


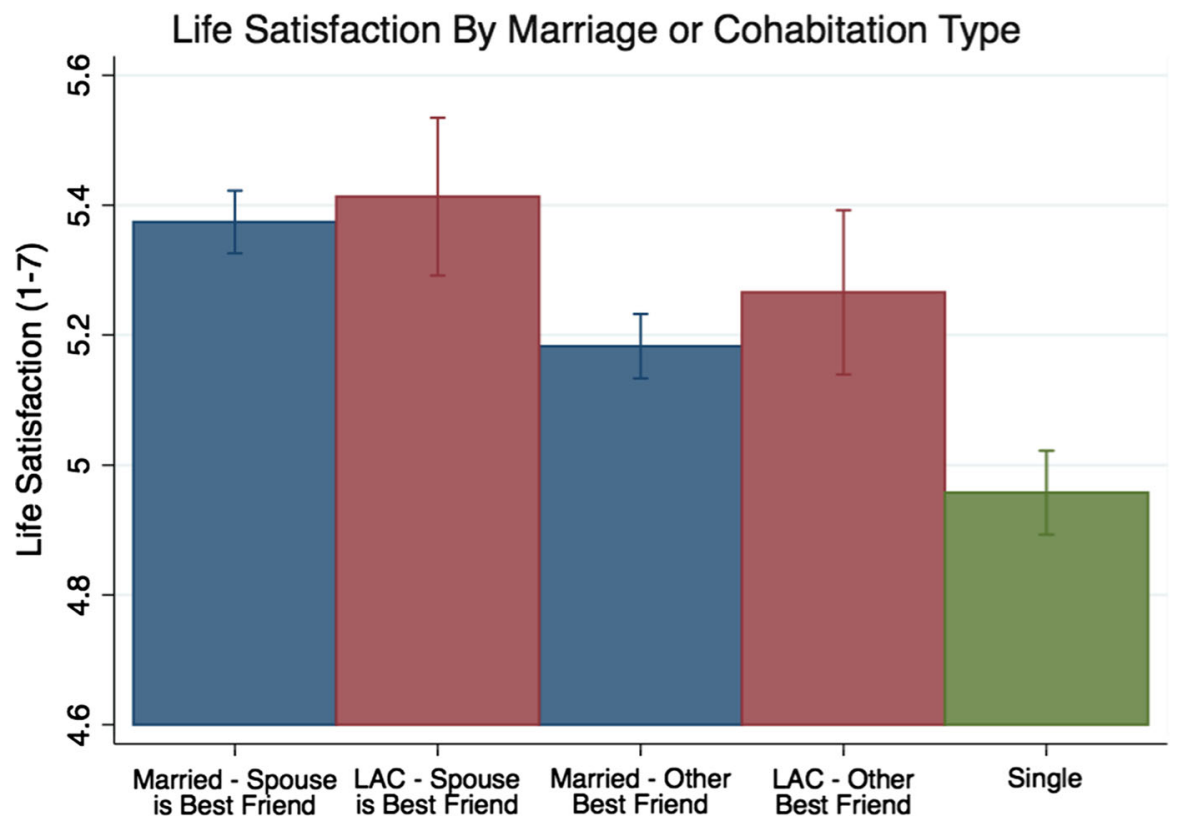

Fig. 4 Life satisfaction by marriage or cohabitation type (including previous Life Sat. Controls)

that life evaluations are not fully determined by genetic and other factors to define immutable long-term individual happiness set points. $^{22}$

Acknowledgements Funding was provided by Canadian Institute for Advanced Research.

Open Access This article is distributed under the terms of the Creative Commons Attribution 4.0 International License (http://creativecommons.org/licenses/by/4.0/), which permits unrestricted use, distribution, and reproduction in any medium, provided you give appropriate credit to the original author(s) and the source, provide a link to the Creative Commons license, and indicate if changes were made.

\section{Appendix}

See Tables 4, 5 and 6.

22 Cummins et al. (2014) argue that set point theory can be reconciled with the idea that life circumstances have long-term impacts on life satisfaction if those in poor life circumstances are interpreted as being unable to achieve their set points. 
Table 4 British household panel survey

Observations are only included if they meet the criteria for inclusion in Table 1 (including that lagged life satisfaction 10 periods ago is available)

Table 5 Summary statistics for the UK annual population survey

\begin{tabular}{llrrll}
\hline Variable & $\mathrm{N}$ & Mean & SD & Min & Max \\
\hline female & 5326 & 0.59 & 0.49 & 0 & 1 \\
age & 5326 & 47.83 & 18.31 & 25 & 98 \\
Lifesatisfaction & 5326 & 5.09 & 1.25 & 1 & 7 \\
married & 5326 & 0.18 & 0.39 & 0 & 1 \\
livingascouple & 5326 & 0.25 & 0.43 & 0 & 1 \\
separated & 5326 & 0.01 & 0.11 & 0 & 1 \\
divorced & 5326 & 0.13 & 0.34 & 0 & 1 \\
widowed & 5326 & 0.13 & 0.34 & 0 & 1 \\
HealthLimits & 5326 & 0.17 & 0.38 & 0 & 1 \\
LogIncome & 5326 & 9.60 & 0.87 & -0.14 & 12.26 \\
\hline
\end{tabular}

\begin{tabular}{lrccrr}
\hline Variable & N & Mean & SD & Min & Max \\
\hline female & 328,665 & $56.19 \%$ & $49.62 \%$ & 0 & 1 \\
age & 328,665 & 51.73 & 17.36 & 16 & 99 \\
satis & 328,665 & 7.44 & 1.90 & 0 & 10 \\
happy & 328,665 & 7.32 & 2.23 & 0 & 10 \\
anxious & 328,665 & 3.09 & 2.90 & 0 & 10 \\
worth & 328,665 & 7.72 & 1.79 & 0 & 10 \\
grosspay & 91,824 & 497.94 & 198.77 & 1 & 788 \\
single & 328,665 & $25.18 \%$ & $43.40 \%$ & 0 & 1 \\
married & 328,665 & $50.70 \%$ & $50.00 \%$ & 0 & 1 \\
separated & 328,665 & $3.51 \%$ & $18.39 \%$ & 0 & 1 \\
divorced & 328,665 & $11.34 \%$ & $31.70 \%$ & 0 & 1 \\
widowed & 328,665 & $9.03 \%$ & $28.66 \%$ & 0 & 1 \\
CivilPartner & 328,665 & $0.25 \%$ & $4.96 \%$ & 0 & 1 \\
\hline
\end{tabular}

Table 6 Lag and lead life satisfaction effects of marriage

\begin{tabular}{lll}
\hline & All people & Only 5+ single periods \\
\hline divorced & $-0.147^{* * * *}$ & 0.149 \\
& $(0.031)$ & $(0.191)$ \\
widowed & $-0.333^{* * * *}$ & -0.216 \\
& $(0.037)$ & $(0.273)$ \\
separated & $-0.362^{* * *}$ & 0.009 \\
& $(0.035)$ & $(0.147)$ \\
age at date of interview & -0.003 & $-0.015^{*}$ \\
& $(0.003)$ & $(0.006)$ \\
agesq & -0.005 & 0.008 \\
& $(0.003)$ & $(0.008)$ \\
OneChild & -0.014 & -0.008 \\
TwoChildren & $(0.013)$ & $(0.043)$ \\
& -0.028 & -0.030 \\
\end{tabular}


Table 6 continued

\begin{tabular}{|c|c|c|}
\hline & All people & Only $5+$ single periods \\
\hline ThreePlusChildren & $\begin{array}{l}-0.006 \\
(0.024)\end{array}$ & $\begin{array}{l}-0.203 \\
(0.106)\end{array}$ \\
\hline PreMarry3 & $\begin{array}{l}-0.006 \\
(0.034)\end{array}$ & $\begin{array}{l}-0.052 \\
(0.080)\end{array}$ \\
\hline PreMarry2 & $\begin{array}{l}0.072 * \\
(0.031)\end{array}$ & $\begin{array}{l}0.059 \\
(0.073)\end{array}$ \\
\hline PreMarry 1 & $\begin{array}{l}0.123 * * * \\
(0.028)\end{array}$ & $\begin{array}{l}0.264 * * * \\
(0.069)\end{array}$ \\
\hline PostMarry1 & $\begin{array}{l}0.262 * * * \\
(0.031)\end{array}$ & $\begin{array}{l}0.453 * * * \\
(0.068)\end{array}$ \\
\hline PostMarry2 & $\begin{array}{l}0.231 * * * \\
(0.034)\end{array}$ & $\begin{array}{l}0.373 * * * \\
(0.081)\end{array}$ \\
\hline PostMarry3 & $\begin{array}{l}0.192 * * * * \\
(0.036)\end{array}$ & $\begin{array}{l}0.339 * * * \\
(0.093)\end{array}$ \\
\hline PostMarry4 & $\begin{array}{l}0.135 * * * \\
(0.037)\end{array}$ & $\begin{array}{l}0.329 * * \\
(0.112)\end{array}$ \\
\hline PostMarry5 & $\begin{array}{l}0.104 * \\
(0.041)\end{array}$ & $\begin{array}{l}0.374 * * \\
(0.136)\end{array}$ \\
\hline PostMarry6PlusOrSinceEntry & $\begin{array}{l}-0.010 \\
(0.028)\end{array}$ & $\begin{array}{l}0.349^{*} \\
(0.140)\end{array}$ \\
\hline PreLAC3 & $\begin{array}{l}-0.054 \\
(0.033)\end{array}$ & $\begin{array}{l}-0.030 \\
(0.049)\end{array}$ \\
\hline PreLAC2 & $\begin{array}{l}-0.034 \\
(0.030)\end{array}$ & $\begin{array}{l}0.047 \\
(0.046)\end{array}$ \\
\hline PreLAC1 & $\begin{array}{l}0.084 * * \\
(0.026)\end{array}$ & $\begin{array}{l}0.114 * * \\
(0.043)\end{array}$ \\
\hline PostLAC1 & $\begin{array}{l}0.225 * * * \\
(0.028)\end{array}$ & $\begin{array}{l}0.208 * * * \\
(0.043)\end{array}$ \\
\hline PostLAC2 & $\begin{array}{l}0.145 * * * \\
(0.033)\end{array}$ & $\begin{array}{l}0.187 * * * \\
(0.051)\end{array}$ \\
\hline PostLAC3 & $\begin{array}{l}0.040 \\
(0.037)\end{array}$ & $\begin{array}{l}0.118 \\
(0.064)\end{array}$ \\
\hline PostLAC4 & $\begin{array}{l}0.077 \\
(0.042)\end{array}$ & $\begin{array}{l}0.098 \\
(0.076)\end{array}$ \\
\hline PostLAC5 & $\begin{array}{l}0.026 \\
(0.049)\end{array}$ & $\begin{array}{l}0.060 \\
(0.090)\end{array}$ \\
\hline PostLAC6PlusOrSinceEntry & $\begin{array}{l}0.119 * * * \\
(0.026)\end{array}$ & $\begin{array}{l}0.061 \\
(0.070)\end{array}$ \\
\hline HealthLimits & $\begin{array}{l}-0.355^{* * * *} \\
(0.011)\end{array}$ & $\begin{array}{l}-0.414 * * * \\
(0.030)\end{array}$ \\
\hline LogIncome & $\begin{array}{l}-0.014 * * * \\
(0.004)\end{array}$ & $\begin{array}{l}-0.026^{* * * *} \\
(0.007)\end{array}$ \\
\hline Constant & $\begin{array}{l}5.682 * * * \\
(0.064)\end{array}$ & $\begin{array}{l}5.703^{* * * *} \\
(0.099)\end{array}$ \\
\hline Observations & 123,860 & 20,127 \\
\hline Adjusted R-squared & 0.227 & 0.190 \\
\hline
\end{tabular}

Standard errors in parentheses

$* p<0.05$; ** $p<0.01$; *** $p<0.001$ 


\section{References}

Anusic, I., Yap, S., \& Lucas, R. (2014a). Testing set-point theory in a Swiss national sample: Reaction and adaptation to major life events. Social Indicators Research, 119, 1265-1288.

Anusic, I., Yap, S., \& Lucas, R. (2014b). Does personality moderate reaction and adaptation to major life events? Analysis of life satisfaction and affect in an Australian national sample. Journal of Research in Personality, 51, 69-77.

Beck, N. (2001). Time-series and cross-sectional data: What have we learned in the past few years? Annual Review of Political Science, 4, 271-293.

Blanchflower, D., \& Oswald, A. (2008). Is well-being U-shaped over the life cycle? Social Science and Medicine, 66(8), 1733-1749.

Boyce, C. (2010). Understanding fixed effects in human well-being. Journal of Economic Psychology, 31(1), $1-16$.

Brickman, P., \& Campbell, D. (1971). Hedonic relativism and planning the good society. In M. H. Apley (Ed.), Adaptation-level theory: A symposium. (pp. 287-302).

Chapman, B., \& Guven, C. (2016). Revisiting the relationship between marriage and wellbeing: Does marriage quality matter? Journal of Happiness Studies, 17(2), 533-551.

Clark, A., \& Georgellis, Y. (2013). Back to baseline in Britain: adaptation in the British Household Panel Survey. Economica, 80(319), 496-512.

Cummins, R., Li, N., Wooden, M., \& Stokes, M. (2014). A demonstration of set-points for subjective wellbeing. Journal of Happiness Studies, 15, 183-206.

Di Tella, R., McCulloch, R., \& Oswald, A. (2003). The macroeconomics of happiness. The Review of Economics and Statistics, 85(4), 809-827.

Dush, C. M. K., \& Amato, P. R. (2005). Consequences of relationship status and quality for subjective wellbeing. Journal of Social and Personal Relationships, 22(5), 607-627.

Frijters, P., \& Beatton, T. (2012). The mystery of the U-shaped relationship between happiness and age. Journal of Economic Behavior \& Organization, 82(2-3), 525-542.

Gove, W., Hughes, M., \& Briggs Style, C. (1983). Does marriage have positive effects on the psychological well-being of the individual? Journal of Health and Social Behavior, 24(2), 122-131.

Graham, C., \& Pozuelo, J. R. (2017). Happiness, stress, and age: how the U curve varies across people and places. Journal of Population Economics, 30(1), 225-264.

Haurant, S. (2013). Getting married in 2013. The Guardian. February 15, 2013.

Helliwell, J., \& Huang, H. (2013). Comparing the happiness effects of real and on-line friends. PLoS ONE, $8(9)$, e 72754.

Helliwell, J., \& Wang, S. (2014). Weekends and subjective well-being. Social Indicators Research, 116, 389-407.

Helliwell, J. F., Barrington-Leigh, C., Harris, A., \& Huang, H. (2010). International evidence on the social context of well-being. In E. Diener, J. F. Helliwell, \& D. Kahneman (Eds.), International differences in well-being (pp. 291-327). New York: Oxford University Press.

Henrich, J., Heine, S., \& Norenzayan, A. (2010). Most people are not WEIRD. Nature, 466, 29.

Lim, C., \& Putnam, R. (2010). Religion, social networks and subjective well-being. American Journal of Sociology, 75(6), 914-933.

Lucas, R. (2007). Adaptation and the set-point model of subjective well-being: Does happiness change after major life events? Current Directions in Psychological Science, 16, 75-79.

Lucas, R., Clark, A., Georgellis, Y., \& Diener, E. (2003). Reexamining adaptation and the set point model of happiness: Reactions to changes in marital status. Journal of Personality and Social Psychology, 84(3), 527-539.

Myers, D. G. (2000). The funds, friends, and faith of happy people. American Psychologist, 55(1), 56.

Peiró, A. (2006). Happiness, satisfaction and socio-economic conditions: Some international evidence. The Journal of Socio-Economics, 35(2), 348-365.

Piper, A. T. (2015). Sliding down the U-shape? A dynamic panel investigation of the age-well-being relationship, focusing on young adults. Social Science and Medicine, 143, 54-61.

Plumper, T., \& Troeger, V. (2007). Efficient estimation of time-invariant and rarely changing variables in finite sample panel analyses with unit fixed effects. Political Analysis, 15(2), 124-139.

Powdthavee, N. (2008). Putting a price tag on friends, relatives, and neighbours: Using surveys of life satisfaction to value social relationships. The Journal of Socio-Economics, 37(4), 1459-1480.

Qari, S. (2014). Marriage, adaptation and happiness: Are there long-lasting gains to marriage? Journal of Behavioral and Experimental Economics, 50, 29-39.

Stack, S., \& Eshleman, J. R. (1998). Marital status and happiness: A 17-nation study. Journal of Marriage and the Family, 60, 527-536. 
Stutzer, A., \& Frey, B. (2006). Does marriage make people happy, or do happy people get married? The Journal of Socio-Economics, 35, 326-347.

Suh, E., Diener, E., \& Fujita, F. (1996). Events and subjective well-being: Only recent events matter. Journal of Personality and Social Psychology, 70(5), 1091-1102.

Switek, M., \& Easterlin, R. A. (2016). Life transitions and life satisfaction during young adulthood. Journal of Happiness Studies, 1-18.

Williams, K. (2003). Has the future of marriage arrived? A contemporary examination of gender, marriage, and psychological well-being. Journal of Health and Social Behavior, 44(4), 470.

Yap, S., Anusic, I., \& Lucas, R. (2012). Does personality moderate reaction and adaptation to major life events? Evidence from the British Household Panel Survey. Journal of Research in Personality, 46(5), 477-488.

Zimmermann, A., \& Easterlin, R. A. (2006). Happily ever after? Cohabitation, marriage, divorce, and happiness in Germany. Population and Development Review, 32(3), 511-528. 